\title{
PENERAPAN IPTEKS BAGI KELOMPOK PETERNAK SAPI DI DESA TUMALUNTUNG KECAMATAN KAUDITAN KABUPATEN MINAHASA
}

\author{
C. L. Kaunang* dan W. B. Kaunang \\ Fakultas Peternakan Universitas Sam Ratulangi Manado, 95115
}

\begin{abstract}
ABSTRAK
Pemeliharaan ternak sapi di Indonesia umumnya masih dilakukan dengan cara tradisional, yaitu ternak dibiarkan mencari makan sendiri, sementara jumlah rumput / hijauan semakin sedikit dan nilai nutrisinya semakin rendah. Keadaan ini akan memberikan efek yang kurang baik terhadap produktivitas sapi. Untuk mengatasinya maka perlu dilakukan upaya pengawetan rumput (silase) dan pemberian pakan tambahan $(\mathrm{UGB}=$ urea gulaaren block), sehingga pakan tetap tersedia sepanjang waktu dan nilai gizin ya menjad lebih baik. Desa Tumaluntung merupakan salah satu desa di Kecamatan Kauditan Kabupaten Minahasa Utara, yang salah satu hasil buminya adalah gula merah (gulaaren). Didesa ini terdapat beberapa kelompok peternak sapi, diantaranya kelompok peternak Mateluntung I dan Mateluntung II. Hasil prasurvei menunjukkan bahwa masalah yang dihadapi oleh kelompok peternak sapi di desa ini adalah masih kurangnya pengetahuan anggota kelompok dalam beternak sapi, kurangnya pengetahuan tentang penyediaan pakan (hijauan) yang kontinu dan berkualitas, serta belum pahamnya pengetahuan tentang pembuatan silase dan UGB.Berdasar fenomena diatas maka telah diadakan pemberdayaan kelompok peternak sapi didalam usaha untuk meningkatkan pengetahuan dan ketrampilan anggota kelompok, sehingga diharapkan penghasilan anggota kelompok menjadi
\end{abstract}

*Korespondensi (Corresponding author) Email : charleskaunang@yahoo.com lebih maksimal. Metode pendekatan yang dilakukan adalah dengan melalui penyuluhan dan pelatihan. Anggota kelompok merespon dengan baik kegiatan penyerapan ipteks ini, hal ini dapat terlihat dari tersedianya rumput gajah dan rumput dwarf. Produk lain yang dihasilkan berupa silase dan UGB.

Kata kunci : KelompokPeternak, Sapi, Silase, UGB

\section{ABSTRACT}

$\begin{array}{lcr}\text { APPLICATION OF } & \text { SCIENCE } & \text { AND } \\ \text { TECHNOLOGY } & \text { FOR CATTLE } \\ \text { BREEDING } & \text { GROUP IN } \\ \text { TUMALUNTUNG } & \text { VILLAGE } \\ \text { KAUDITAN SUB DISTRICT NORTH }\end{array}$
MINAHASA. Cattle's breeding in Indonesia is generally still done traditionally, which the cattle are allowed to feed themselves, while the numbers of grass / forage become less and lower in nutritional value. This will affect on cattle productivity adversely. To overcome this, it is necessary to peform of a grass silage preservation and supplemental feeding using an urea-sugar palm-block (UGB), so the feed remains available all the time and the nutritional value becomes better. Tumaluntung is a village in KauditanSubdistrict of North Minahasa Regency, which produces brown sugar as its main crop. In this village there are several groups of cattle bereeders, among them group Mateluntung I and Mateluntung II.

Pre-survey showed that the problems faced by the cattle breeders in this village were lack of knowledge by group 
members to raise cattle, lack of knowledge to provide qualified of forage sustainability, lack of knowledge about making silage and UGB. Therefore, we had done an empowerment cattle breeder groups to increase their knowledge, skills and their income. Method was carried out through counselling and training. Members of the group responded well to this application of science and technology, this can be seen from the availability of elephant grass and dwarf grass. Other products produced were silage and UGB.

Keywords : Group of breeders, cattle, silage, UGB

\section{PENDAHULUAN}

$\underline{\text { Analisis Situasi }}$

Kabupaten Minahasa Utara memiliki luas wilayah sebesar 1.059.24 $\mathrm{Km}^{2}$ yang terbagi dalam 10 kecamatan dan 125 desa. Adapun batas - batas wilayah adalah : Sebelah utara dengan Kabupaten Kepulauan Sangihe, Laut Sulawesi dan Laut Maluku; sebelah Timur dengan kota Bitung, sebelah Selatan dengan Kabupaten Minahasa dan sebelah Barat dengan Kota Manado.

Jumlah penduduk Minahasa Utara tercatat sebanyak 191.036 jiwa. Penduduk yang bekerja atau sementara tidak bekerja berjumlah 81.685 orang atau 91.02 persen dari total angkatan kerja, sementara penduduk yang tidak bekerja / menganggur berjumlah 8.056 orang atau tingkat pengangguran sebesar8,98 persen. Angka pengangguran ini cukup tinggi sehingga dibutuhkan lapangan pekerjaan. Sektor pertanian merupakan lapangan pekerjaan bagi semua angkatan kerja.

Sektor pertanian di Minahasa Utara mencakup subsektor tanaman pangan, perkebunan, peternakan, perikanan dan hortikultura. Pertanian tanaman pangan didominasi oleh padi, jagung, kacang tanah, kacang kedelai, ubi kayu dan ubi jalar. Perkebunan kelapa juga sangat mendominasi di daerah ini. Kelapa banyak dibudidayakan di daerah dataran sampai bergelombang. Lahan dibawah pohon kelapa banyak dimanfaatkan masyarakat petani dengan ditanami jagung, padi ladang dan pisang. Pola usaha tani terpadu ini menunjukkan pertumbuhan yang baik (BPS Minahasa Utara, 2012).

Kecamatan Kauditan merupakan salah satu kecamatan yang ada di Kabupaten Minahasa Utara. Ternak sapi merupakan salah satu sumber pendapatan masyarakat Kecamatan Kauditan. Populasi ternak bertambah otomatis produksi daging meningkat. Dampak berikutnya yang secara langsung dirasakan petani adalah peningkatan pendapatan dan kesejahteraannya.

Pembangunan pertanian dan peternakan saling mendukung dan menguntungkan, sehingga sistem pertanian terpadu memberi manfaat yang 
besar bagi keduanya (Salendu, 2012; Ellydan Salendu,2013). Disatu sisi, hasil pertanian seperti jagung, ubi kayu, rumput-rumputan, limbah pertanian dapat dimanfaatkan sebagai pakan ternak sehingga ada nilai tambahnya. Secara tidak langsung kebutuhan pakan (hijauan dan konsentrat) bagi ternak dapat dipenuhi.

Ternak sapi di Kecamatan Kauditan cukup populer sebagai salah satu usaha, karena dianggap sebagai tabungan. Seratus persen usaha ini dilakukan oleh peternak rakyat yang pada umumnya belum menerapkan konsep usaha intensif.

Pengembangan ternak sapi di desa Tumaluntung Kecamatan Kauditan dilakukan oleh anggota kelompok dengan sistem tradisional. Kelompok yang mengembangkan ternak sapi di desa ini diantaranyaadalah Kelompok PeternakSapiMateluntung I dan II.

Ternak sapi digunakan sebagai tenaga kerja untuk mengangkut produk tanaman kelapa. Artinya adanya ternak sapi sangat berkontribusi terhadap proses produksi tanaman kelapa. Memelihara sapi sangat menguntungkan, karena tidak hanya menghasilkan daging dan susu, juga menghasilkan pupuk kandang dan sebagai hewan kerja (Siregar, 1996).

Pengetahuan anggota kelompok untuk pengembangan hijauan berkualitas masih sangat rendah. Padahal menurut Mariyono dan Romjali (2007), pengembangan ternak sapi potong dapat dilakukan dengan cara pola integrasi tanaman ternak melalui pndekatan berkelanjutan. Pendekatan berkelanjutan dapat dilakukan dengan biaya murah dan optimalisasi pemanfaatan limbah.

Berdasarkan kondisi dan pemikiran di atas perlu dilakukan pemberdayaan kelompok peternak sapi. Pemberdayaan ini dilakukan melalui penerapan teknologi dengan tujuan untuk meningkatkan pengetahuan dan ketrampilan anggota kelompok dalam meningkatkan manajamen usaha ternak sapi. Peningkatan manajeman usaha ternak sapi ini diharapkan agar pendapatan anggota kelompok lebih maksimal. Pelatihan yang akan dilaksanakan berupa pembuatan silase dan UGB (Urea GulaAren Blok).

\section{Permasalahan Mitra}

Pada umumnya usaha peternakan sapi masih merupakan sambilan, belum dikelola dengan manajemen bisnis yang profesional. Peningkatan skala usaha, penanganan yang lebih intensif, penggunaan berbagai hasil penelitian dibidang pakan ternak yang dilakukan oleh perguruan tinggi dan lembaga penelitian lainnya terbukti mampu meningkatkan produktivitas ternak. 
Lahan di bawah pohon kelapa milik anggota kelompok tidak dimanfaatkan dengan maksimal. Pakan yang semakin baik kualitasnya dan jumlah yang diberikan sesuai kebutuhan maka makin besar tenaga yang ditimbulkan dan makin besar pula energi yang tersimpan dalam bentuk daging (Menegristek, 2000). Sapi dalam masa pertumbuhan dan sedang menyusui memerlukan pakan yang memadai dari segi kualitas dan kuantitasnya. Permasalahannya adalah anggota kelompok sering mengalami kesulitan dalam memperoleh hijauan, sehingga produktivitas ternak sapi rendah. Menurut Susanti dkk. (2013), pakan ternak adalah sumber energi utama untuk pertumbuhan ternak sapi, sementara permasalahan utama yang sering dihadapi peternak adalah masalah pakan.

Hasil prasurvei menunjukkan bahwa masalah prioritas yang dihadapi oleh Kelompok PeternakSapi Mateluntung adalah :

1. Kurangnya pengetahuan tentang pemanfaatan lahan untuk hijauan pakan ternak.

2. Kurangnya pengetahuan tentang penyediaan pakan (hijauan) yang kontinu dan berkualitas. Hal ini menyebabkan berat badan ternak sapi rendah. Apabila anggota
3. kelompok dapat menyediakan pakan (hijauan) secara kontinu dan berkualitas maka produksi daging sapi akan meningkat.

4. Kurangnya pengetahuan peternak tentang pengawetan hijauan pakan (silase) dan pakan tambahan/suplemen seperti UGB. Ternak juga memerlukan suplemen yang dimaksudkan untuk melengkapi zat-zat makanan yang diperoleh tubuh sehingga terdapat komposisi yang seimbang untuk berproduksi secara optimal (Hatmono dan Hastoro, 1977). Pengawetan dalam bentuk silase dilakukan untuk mengatisipasi apabila terjadi over produksi atau apabila musim kemarau yang panjang.

\section{METODE PENELITIAN}

Berdasarkan permasalahan prioritas Kelompok Peternak Sapi Mateluntung di desa Tumaluntung maka diperlukan pemberdayaan terhadap kelompok tersebut. Pemberdayaan tersebut dilakukan dengan dua metode yaitu penyuluhan dan pelatihan.

Setelah dilakukan penyuluhan terhadap anggota kelompok, selanjutnya dilakukan pelatihan. Pelatihan tersebut 


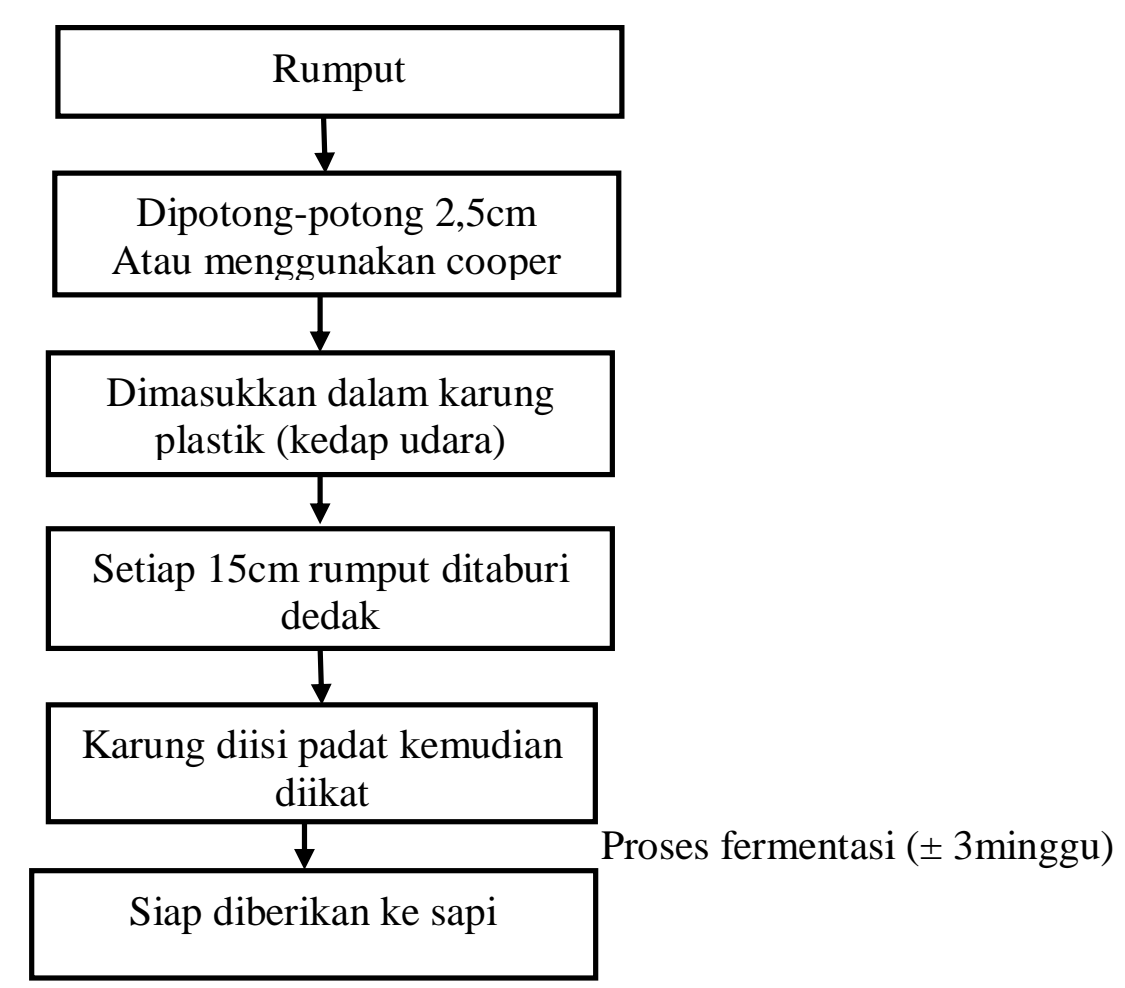

Gambar 1. Cara Pembuatan Silase (Ridwandan Widyastuti, 2003)

Bahan I :

Urea $(200 \mathrm{~g})$

Dedak padi $(4 \mathrm{~kg})$

Bungkil kelapa,

Jagung,Tepungikan $(1 \mathrm{~kg})$

Garam,Semen $(200 \mathrm{~g})$

Mineral (400 g)

Dicampur dan dipanaskan diatas

api \pm 5 menit
Bahan II :

Gula Aren (2 kg)

Dihancurkan dengan cara

penambahan air

Bahan I dan Bahan II

Di campur sambil terus diaduk diatas api

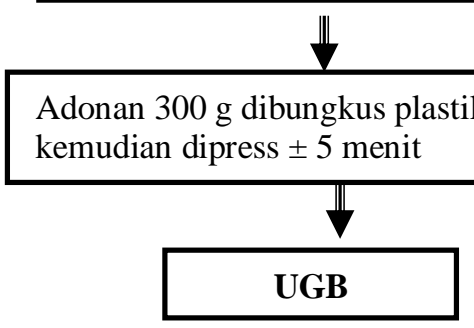

Gambar 2. Cara Pembuatan UGB (Kaunang,2000) 
memanfaatkan beberapa orang mahasiswa.

a. Penanaman hijauan berupa rumput. Penanaman rumput dilakukan pada lahan yang belum dimanfaatkan dengan menggunakan rumputgajahdanrumput gajah dwarf (rumput gajah kerdil)

b. Pembuatan silase dan UGB tampak pada gambar 1 dan 2

\section{HASIL DAN PEMBAHASAN}

Pembangunan pertanian dan peternakan di Minahasa Utara saling mendukung dan menguntungkan, sehingga sistem pertanian terpadu memberi manfaat yang besar bagi keduanya. Menurut Ahmed et al. (2011), pola usaha tani terintegrasi adalah sistem pertanian terbaik dalam hal sumber daya, efisiensi, produktivitas, produksi dan suplai makanan.

Usaha ternak sapi adalah salah satu usaha yang dapat diandalkan oleh Kelompok Peternak Sapi Tumaluntung I dan II Desa Tumaluntung. Produktivitas ternak sapi dapat ditingkatkan dengan melibatkan anggota kelompok maupun pemerintah. Berkaitan dengan pemikiran tersebut, maka anggota kelompok telah diberdayakan dengan cara pemberian penyuluhan dan pelatihan. Materi penyuluhan menyangkut manajemen hijauan makanan ternak serta hal-hal yang berkaitan dengan manajemen usaha ternak sapi.

Keberhasilan usaha ternak sapi ditentukan oleh 3 unsur yang saling terkait yaitu bibit, pakan dan manajemen. Keberhasilan usaha tersebut tergantung dari karakteristik anggota kelompok. Karakteristik anggota kelompok dapat dilihat dari umur dan tingkat pendidikan mereka.

Keberhasilan usaha ternak sapi ditentukan oleh umur anggota kelompok. Umur anggota kelompok berkisar antara 37 - 47 tahun. Rata - rata umur anggota kelompok adalah 41,5 tahun. Kondisi ini menunjukkan bahwa umur anggota kedua kelompok dikategorikan masih produktif. Mereka memiliki kemampuan fisik yang cukup kuat untuk melaksanakan kegiatan usaha tani. Menurut Kiswanto dkk. (2004), adopsi teknologi erat kaitannya dengan produktivitas usaha. Lebih lanjut dinyatakan bahwa umur merupakan salah satu faktor yang dapat mempengaruhi produktivitas usaha penggemukan sapi.

Rata - rata tingkat pendidikan anggota kelompok adalah SMA. Tingkat pendidikan mempengaruhi adopsi teknologi anggota kelompok. Menurut Saridewi dan Siregar (2010), proses adopsi teknologi merupakan proses perubahan periaku melalui tahapan- 
tahapan mengetahui, memperhatikan, menilai, mencoba dan menerapkan. Sementara menurut Kiswanto dkk. (2004), tingkat pendidikan yang semakin tinggi memungkinkan dapat mengubah sikap dan perilaku untuk bertindak lebih rasional. Tindakan ini memberi peluang untuk lebih berhasil dalam mengelola usaha tani.

Masalah yang dihadapi dalam pengembangan ternak sapi adalah pakan hijauan yang tidak tersedia. Ternak sapi hanya diberi rumput lapangan dan limbah pertanian. Ternak sapi digembalakan di lahan perkebunan kelapa atau lahan yang kering lainnya dan dibiarkan mengkonsumsi rumput yang liar. Sementara menurut Abdullah dkk. (2013), hijauan merupakan salah satu penentu keberhasilan peternakan ruminansia, sehingga perlu perhatian khusus terhadap ketersediaan dan kualitas hijauan di suatu wilayah.

Untuk memenuhi kebutuhan hiajauan makanan ternak yang sesuai standar, maka anggota kelompok harus menyiapkan lahan hijauan makanan ternak. Penerapan ipteks yang telah dilakukan adalah introduksi hijauan berkualitas, dengan penanaman rumput gajah dan rumput dwarf (rumput gajah kerdil). Penanaman rumput ini direspon dengan baik oleh anggota kelompok.
Untuk menyediakan pakan ternak secara kontinu, diperlukan suatu teknologi penyiapan pakan yang tidak hanya tahan simpan tetapi juga mengandung nutrien yang sesuai dengan kebutuhan ternak. Salah satunya adalah dengan teknik silase (Reiber et al., 2010).

Anggota kelompok juga dilatih untuk mengawetkan rumput dalam bentuk silase. Hal ini dilakukan untuk mengatasi apabila terjadi kelebihan produksi dan dapat dimanfaatkan pada musim kemarau. Menurut Haryanto (2009), kemampuan produksi ternak yang relatif rendah berkaitan dengan kualitas dan kuantitas pakan yang tersedia sepanjang tahun. Ketersediaan pakan yang berfluktuasi dan tidak mencukupi kebutuhan gizi ternak untuk mengekspresikan potensi genetiknya secara maksimal, menyebabkan produktivitas ternak rendah masalah tersebut harus diatasai melalui pemanfaatan teknologi.

Pembuatan silase adalah : Rumput segar dipotong potong $2-5 \mathrm{~cm}$, kemudian dimasukkan kedalam kantong plastik kedap udara. Setiap $15 \mathrm{~cm}$ rumput, ditaburi dengan dedak, demikian seterusnya sampai kantong plastik terisi penuh dan padat. Setelah itu kantong plastik ditutup dengan rapat (diikat). Proses pembuatan berlangsung selama 21 hari. Menurut Saun dan Heinrich (2008), 
silase yang berkualitas baik akan memiliki warna seperti bahan asalnya. Pembuatan silase ini direspon dengan baik oleh anggota kelompok (RidwandanWidyastuti,2003).

Proses pembuatan UGB adalah : Bahan - bahan I yang terdiri dari urea, dedak padi, bungkil kelapa, garam dan mineral, dicampur dan dipanaskan di atas api selama \pm 5 menit. Bahan II yang adalah gula aren, dihancurkan dengan cara penambahan air. Bahan I dan II dicampur, sambil terus diaduk diatas api selanjutnya, adonan tersebut sebanyak 300 gr dicetak dengan menggunakan tempurung, di press sekitar \pm 5 menit, dan terbentuklah UGB. Pembuatan UGB ini direspon dengan baik oleh anggota kelompok.

$$
\text { Pakan tambahan (seperti UGB) }
$$
dikonsumsi ternak dengan cara dijilat atau diberikan dengan cara meletakkannya di kotak pakan. Pakan tambahan ini diberikan pada pagi hari dengan jumlah yang sesuai dengan tingkat konsumsi yang dianjurkan pada setiap jenis ternak. Meskipun jumlahnya melebihi kebutuhan, tetapi biasanya ternak akan membatasi sendiri (Hatmono dan Hastoro, 1997). Nurwahidahdkk.(2016), menyatakan bahwa pemberian suplemen dapat meningkatkan performans ternak, yang ditunjukkan dengan peningkatan berat badannya.

\section{KESIMPULAN DAN SARAN}

Anggota Kelompok Peternak Sapi Mateluntung I dan II merespon dengan baik kegiatan penerapan ipteks yang dilakukan melalui penyuluhan dan pelatihan. Hal ini terlihat dari tersedianya lahan hijauan yang berupa rumput gajah dan rumput dwarf. Produk lain yang dihasilkan adalah berupa silase dan UGB.

Hal yang dapat disarankan adalah perlunya bantuan dan pendampingan baik dari pemerintah setempat maupun dari perguruan tinggi dalam kegiatan penerapan ipteks bagi masyarakat desa.

\section{DAFTAR PUSTAKA}

Abdullah, L., P.D.M.H Karti dan S. Hardjosoewignjo. 2013. Reposisi Tanaman Pakan Dalam Kurikulum Fakultas Peternakan. Lokakarya Nasional Tanaman Pakan.

Ahmed, M. K. , K. Zander and S. T. G. Garnett. 2011. Sosioeconomic Aspect of Rice - Fish Farming in Bangladesh. Australian J. Agric. and Res. 55 (2):199 - 219

BPS Minahasa Utara, 2012. Minahasa Utara Dalam angka Badan Pusat Statistik Kabupaten Minahasa Utara

Elly,F.H and A.H.S. Salendu.2013. Environmentally friendly and sustainable local cattle development model in Dumoga Barat Subdistrict of Bolaang 
Mongondow Regency. European Journal of Scientific Research. 115 (2) : 335-341

Haryanto, B. 2009. Inovasi Teknologi Pakan Ternak Dalam Sistem Integrasi Tanaman - Ternak Bebas Limbah Mendukung Upaya Peningkatan Produksi Daging. Pengembangan inovasi pertanian 2 (3) : $163-179$.

Hatmono, H. dan I. Hastoro. 1997. UMB Pakan Suplemen Ternak Ruminansia. Trubus Agriwidya Ungaran.

Kaunang,C.L. 2000. Suplementasi UMB atau UGB pada jerami padi dengan atau tanpa amoniasi terhadap kecernaan ternak sapi lokal. J. Zootek. 10: 30-36.

Kiswanto, A., Prabowo dan Widyantoro. 2004. Transformasi Struktur Usaha Penggemukan Sapi Potong di Lampung Tengah. Prosiding Seminar. Balai Penelitian dan Pengembangan Pertanian. Deptan.

Mariyono dan Romjali 2007. Petunjuk Teknis Teknologi Inovasi Pakan Murah untuk Usaha Peternakan sapi Potong. BalaiPenelitian dan Pengembangan Pertanian. Deptan. Jakarta

Menegristek. 2000. Budidaya Ternak Sapi Potong. Kantor Deputi Menegristek Bidang Pendayagunaan dan Pemasyarakatan IPTEK. Jakarta

Nurwahidah,J. A.I Tolleng dan M.N. Hidayat.2016. Pengaruh pemberian pakan konsentrat dan urea molasses blok (UMB) terhadap pertambahan berat badan sapi potong. Jurnal UIN Alaudin. 2 (2): 111-121

Reiber, C. K.R Schultze, M. Peters, P. Lentes and V Hoffmann. 2010. Promotion and adoption of silase technological in drought- constrained areas of Honduras. Tropical Grassland 44 : 231-245

Ridwan,R. dan Y. Widyastuti.2003. Membuat silase: upaya mengawetkan dan mempertahankan nilai nutriusi dan hijauan pakan ternak.Warta Biotek LIPI 15 (1):9-14.

Salendu A.H.S. 2012. Perspektif Pengelolaan Agroekosistem Kelapa - Ternak Sapi di Minsel. Disertasi Unibraw Malang.

Saridewi, T R dan A N. Siregar 2010. Hubungan antara peran penyuluh dan adopsi teknologi oleh petani terhadap peningkatan produksi padi di Kabupaten Tasikmalaya. Jurnal Penyuluhan Pertanian 5(1): 55-61

Saun, R J V and A.J. Heinrich. 2008. Trouble Shorting Silase Problem. In Procedings of the MildAtlantic Conference. Pensylvania. Page 2-10

Siregar S. 1996. Usaha Ternak Sapi. Penerbit Yayasan Kanisius Yogyakarta

Susanti, AE; A. Prabowo dan J. Karman 2013. Identifikasi dan pemecahan masalah penyediaan pakan sapi dalam mendukung usaha peternakan rakyat di SUMSEL. Prosiding Seminar Nasional Peternakan Berkelanjutan. Fakultas Peternakan UNPAD. Hal: 127-132 